\title{
Editorial
}

\section{Are Alternatives to the European Arrest Warrant Underused? The Case for an Integrative Approach to Judicial Cooperation Mechanisms in the EU Criminal Justice Area}

In the application of the European arrest warrant (EAW) mechanism, the principles of mutual trust and mutual recognition have come under the pressure of serious fundamental rights concerns in some EU Member States in particular. The latest chapter in a yet unfinished tale has been written on 17 December 2020 , when the EU Court of Justice handed down its preliminary ruling in two cases in which Poland had requested the Dutch authorities to surrender two Polish nationals (joined cases $L / P) .{ }^{1}$ In its preliminary ruling, the Court has, amongst other things, upheld the requirement for executing authorities to still carry out the second, individualised, step of the two-step test that has been developed in Aranyosi/Căldăraru and got confirmed in $L M .^{2}$ It therefore remains required for executing authorities to assess whether there is a real risk that the sought person him/herself will be subject of a breach of the fundamental right in respect of which it was established (under the first element of

$1 \quad$ ECJ 17 December 2020, joined cases C-354/20 PPU and C-412/20 PPU, in proceedings relating to the execution of European arrest warrants issued in respect of L and P, ECLI:EU:C:2020:1033 (hereinafter in footnotes briefly referred to as the $L / P$ case).

2 ECJ 5 April 2016, joined cases C-404/15 and C-659/15 PPU, in proceedings relating to the execution of European arrest warrants issued in respect of Pál Aranyosi and Robert Căldăraru, ECLI: EU:C:2016:198, par. 91-94 (hereinafter in footnotes briefly referred to as the Aranyosi/ 
the two-step test) that there are 'systemic of generalised deficiencies' in the issuing Member State in safeguarding that right.

One reason for the Court not to drop the requirement of the individual assessment (the second element of the two-step test) is that it would run counter the objective of the European arrest warrant mechanism to combat the impunity of fugitives. ${ }^{3}$ In this contribution, I will explore the background of this 'prevention-of-impunity argument' as well as its actual validity in the specific context of judicial cooperation between EU Member States. I will argue that the 'prevention-of-impunity argument' cannot convincingly be invoked without fair attention for cooperation mechanisms other than the EAW instrument through which a high level of impunity across the EU could be prevented.

\section{Fundamental Rights Protection in EAW Cases: the CJEU's Reaffirmation of the Two-Step Test in Joined Cases C-354/20 PPU (L) and C-412/20 P PU (P)}

Both of the preliminary requests that have led to the Court's much-debated decision in the joined cases $L / P$ were made in proceedings in the Netherlands and concerned European arrest warrants that were issued by Poland. The Polish authorities had sought the surrender of two Polish citizens, one for the purpose of prosecution $(L)$, the other for the purpose of executing a custodial sentence $(P)$.

In both proceedings, the referring Dutch court (the District Court of Amsterdam) had established the existence of systemic and fundamental shortcomings relating to the independence of the Polish judiciary - a core aspect of the right to a fair trial. The referring court therefore wondered, amongst other things, whether it could drop the requirement - by virtue of previous caselaw on the matter - to examine the personal situations of the persons whose surrender was sought by the Polish authorities. ${ }^{4}$ The referring court itself clearly hinted that the Court should indeed drop this requirement, for instance because the systemic and fundamental nature of the established shortcomings

Căldăraru case); ECJ 25 July 2018, C-216/18 PPU, in proceedings relating to the execution of European arrest warrants issued against LM, ECLI:EU:C:2018:586, par. 68 (hereinafter in footnotes briefly referred to as the $L M$ case).

3 L/P case, par. 62-64.

4 This follows from the referring court's second and third preliminary questions, see $L / P$ case, par. 21. 
would automatically imply that the right to an independent tribunal is no longer guaranteed for anyone who has to appear before a Polish court. ${ }^{5}$

But the Court did not follow the referring court's suggestion. Instead, it has sticked to its position that the finding of 'systemic or generalised deficiencies' alone cannot be relied on to justify a refusal to execute EAw's. ${ }^{6}$ Thereby, the Court has confirmed its previous verdict in the case of $L M$ in which it had ruled that the possibility of refusal 'presupposes a two-step examination' - the same two-step assessment as the Court had already applied in relation to substandard prison conditions which may raise an issue under the absolute right envisaged in Article 4 of the Charter (the right to remain free from inhumane and degrading treatment). ${ }^{7}$ Whereas the first step requires the executing authority to establish whether there is evidence of 'systemic or generalised deficiencies' concerning the independence of the judiciary in the issuing Member State, the second step requires a precise assessment of whether and to what extent the requested person will run a real risk that the essence of his right to a fair trial will be violated after being surrendered to the issuing Member State, due to the established deficiencies in the independence of the judiciary. ${ }^{8}$ It follows clearly from the $L / P$ judgment that according to the Court, this second step can neither be skipped nor be merged with the first step; the Court keeps requiring a separate assessment of the requested person's personal situation. ${ }^{9}$

Much has been said and much there is to be said about the outcome in the joined cases $L / P$. In this contribution, the focus will be on one of the arguments that the Court has relied on to maintain the second step. It concerns the argument that dropping the second step of the two-step examination would lead to a high risk of impunity. According to the Court, the acceptance that the establishment of systemic and generalised deficiencies with respect to the independence of the judiciary in Poland would suffice to presume that any requested person would run a real risk that his/her right to a fair trial will be violated following his/her surrender to Poland, due to these deficiencies,

5 See $L / P$ case, par. ${ }^{18-19}$. For those reading Dutch it might be interesting to take note of the underlying interlocutory judgment of the referring court itself, because it provides a more elaborate explanation of its viewpoints, see District Court of Amsterdam 31 July 2020 (interlocutory judgment), ECLI:NL:RBAMS:2O20:3776, par. 26.

6 See $L / P$ case, par. 53 .

7 See the aforementioned Aranyosi/Căldăraru case, supra n. 2.

$8 L M$ case, par. 61 et seq (explaning the first step) and par. 68 et seq (explaining the second step).

9 As stated by the Court in the $L / P$ case, par. 56 : ' It should be pointed out that, as was noted in paragraphs 53 to 55 of this judgment, the two steps of that examination involve an analysis of the information obtained on the basis of different criteria, with the result that those steps cannot overlap with one another.' 
would amount to the acceptance of 'an automatic refusal' of any EAW issued by Poland and, consequently, of a 'de facto suspension of the implementation of the European arrest warrant mechanism in relation to that Member State' (i.e. Poland). According to the Court, such an outcome would be at odds with the fact that the only suspension allowed for under the Framework Decision EAW (FD EAW $)^{10}$ must be based on a decision of the European Council, as envisaged in Article 7 of the EU Treaty (TEU).. ${ }^{11}$ The Court went on to add a further argument to why it was not ready to accept such an automatic refusal of Polish EAW's. Following its claim that the EAW mechanism aims 'in particular' to combat the impunity of persons who are not present on the territory of the Member State in which they allegedly had committed an offence, the Court invoked this very objective to rule out the possibility of skipping the second, individualised step: ${ }^{2}$

"Such an interpretation would entail a high risk of impunity for persons who attempt to flee from justice after having been convicted of, or after they have been suspected of committing, an offence, even if there is no evidence, relating to the personal situation of those individuals, to suggest that they would run a real risk of breach of their fundamental right to a fair trial if they were surrendered to the Member State which issued the European arrest warrant concerned."13

With reference to both written and oral observations, submitted by the European Commission and a few Member States, the Advocate-General had invoked the same argument in his opinion on the $L / P$ case, foreseeing 'numerous criminal offences going unpunished' would the referring court's suggestion be followed and hence the requirement of the second step be dropped in worrying situations such as in Poland. It could, moreover, undermine the rights of victims of crime, as was pointed out by the Belgian government. Even stronger words were used by the Dutch government which apparently had mentioned 'the duty to prevent impunity'.14

10 See recital 10 of the preamble to Framework Decision 2002/584/JHA of 13 June 2002 on the European arrest warrant and the surrender procedures between Member States, OJ 2002, L 190/1.

$11 \quad L / P$ case, par. $57-59$.

12 Idem, par. 62-64.

13 Idem, par. 64.

14 Opinion of Advocate-General Campos Sánchez-Bordona, delivered on 12 November 2020 in the joined cases C-354/20 PPU (L) and C-412/20 PPU (P), ECLI:EU:C:2020:925, par. 50-51. 


\section{Fundamental Rights Protection and Prevention of Impunity: a Delicate Relationship}

It is not the first time that the EU Court of Justice has explicitly invoked the prevention of impunity as a relevant interest in assessing the scope of fundamental rights protection in a criminal law context. It did so earlier in the case of Spasic on the scope of the ne bis in idem principle. In this case, the Court was asked whether the so-called 'enforcement condition' laid down in the ne bis in idem provision of Article 54 CISA, ${ }^{15}$ would provide an acceptable restriction of the more extensive protection against double prosecutions/punishment i.e. without such an additional condition applicable - under Article 50 of the Charter. The Court ruled in the affirmative, considering that the ne bis in idem principle has a twofold aim: to ensure legal certainty and to prevent impunity. It then determined that in view of the principle's aim to avoid impunity, the application of the 'enforcement conditions' constitutes a proportionate limitation of the ne bis in idem principle. ${ }^{16}$

The Spasic ruling illustrates that the Court has earlier relied on an impunity rationale ${ }^{17}$ to justify the limitation of fundamental rights protection in criminal proceedings. ${ }^{18}$ In the $L / P$ case, the impunity rationale was relied on again, though this time in order to justify the limits to fundamental rights protection in the context of surrender proceedings. ${ }^{19}$ As mentioned before, the Court did so with reference to the objective of the EAw mechanism which is, according to the Court, in particular to combat the impunity of persons who are residing

15 I.e. the Convention Implementing the Schengen Agreement.

16 ECJ 27 May 2014, C-129/14 in the criminal proceedings against Zoran Spasic, ECLI:EU:C: 2014:586, par. 72 .

17 Elsewhere indicated as a 'security rationale', V. Mitsilegas, EU Criminal Law after Lisbon. Rights, Trust and the Transformation of Justice in Europe, Oxford: Hart Publishing 2016, p. 183, and repeated in V. Mitsilegas, 'Conceptualising Impunity in the Law of the European Union', in: L. Marin \& S. Montaldo (eds.), The Fight Against Impunity in EU Law, Oxford: Hart Publishing (Hart Studies in European Criminal Law) 2020, p. 30. It deserves to be mentioned here that the Court's decision in the Ognyanov case (ECJ 8 November 2016, C-554/14, in the criminal proceedings against Atanas Ognyanov, ECLI:EU:C:2016:835) has also been interpreted as favouring impunity over the individual's interests, i.e. the individual's social rehabilitation, see A. Rosanó, 'Clash of the Titans: The Fight against Impunity versus Social Rehabilitation and the Protection of Fundamental Rights within the Framework of Prisoner Transfers in the EU', in: Marin \& Montaldo 2020, p. 198-199.

18 J.W. Ouwerkerk, 'Fundamental Rights-Oriented Repression in the EU? Exploring the Potential and Limits of an Impunity Rationale to Justify Criminalisation in the EU Legal Order', in: Marin \& Montaldo 2020, supra note 17, p. 51-52. 
on the territory of a Member State other than the one on whose territory the offence was allegedly committed. ${ }^{20}$

Fighting impunity is in itself a legitimate endeavour in criminal justice systems, and equally so in the EU criminal justice area. In this latter context, efforts to prevent impunity are particularly prompted by the very nature of the EU area of freedom, security and justice, i.e. an area without internal frontiers in which individuals are free to move across the entire EU territory. In order to prevent criminals to escape prosecution and punishment by the mere use of their right to free movement, powers have been conferred upon the EU to enhance cross-border cooperation, amongst others by implementing the principle of mutual recognition (of which the EAW mechanism is the first representation).

Be that as it may, the need to fight impunity in the borderless EU criminal justice area can never be the sole interest; it is widely shared that criminal justice is about striking the right balance between effective law enforcement and adequate judicial protection (or: due process). ${ }^{21}$ It was therefore welcomed and applauded that the Court in Aranyosi/Căldăraru had explicitly accepted - for the first time in the mutual recognition era - that the assumed level of trust is rebuttable in exceptional cases. This was taken by many as a turning point, marking that the Court has started to follow a new avenue in EAw cases, namely the avenue of a restored balance between effective law enforcement (or: fighting impunity) and fundamental rights compliance - whereas until then emphasis would too one-sidedly had been placed on the objective of enforcement. ${ }^{22}$ In the case of $L / P$, the Court was invited to emphasize the objective of fundamental rights protection even stronger than it already did in Aranyosi/Căldăraru and, later on, also in LM. However, as described in the previous section, that invitation has been declined. Even in such a worrying situation as in the case at hand, the Court was not ready to drop the requirement of

20 Idem, par. 62. On this objective, see also ECJ 6 December 2018, C-551/18 PPU in the proceedings relating to the execution of a European arrest warrant issued against $\mathrm{IK}$, ECLI:EU:C:2018:991, par. 39.

21 J. Ouwerkerk, 'Criminal Justice beyond National Sovereignty. An Alternative Perspective on the Europeanisation of Criminal Law', European Journal of Crime, Criminal Law and Criminal Justice 2015, p. 11-31.

22 See amongst others Mitsilegas 2020, supra note 17, p. 24-25; L. Mancano, 'A New Hope? The Court of Justice Restores the Balance Between Fundamental Rights Protection and Enforcement Demands in the European Arrest Warrant System', in: C. Brière and A. Weyembergh (eds.), The Needed Balances in EU Criminal Law (Oxford and Portland, Oregon: Hart Publishing 2018, pp. 285-312; T. Marguery, 'Rebuttal of Mutual Trust and Mutual Recognition in Criminal Matters: Is “Exceptional” Enough?', European Papers 2016, p. 
the second step of individualised assessment also because of the high risk of impunity that would result from it.

True, dropping the second element of the examination required in cases of serious fundamental rights concerns would certainly lead to an increase of impunity for persons who reside outside the territory of the Member State in which they are suspected of a crime or have already been convicted. Without applying the individual assessment which is required under this second element of the examination, refusals to surrender are simply more likely to occurat least towards Poland - and upon such refusals requested persons will have to be released from detention in the executing Member State. This became also apparent in one of the surrender cases that led to the Court's decision in $L / P$. Whereas $P$ - whose surrender was sought for the purpose of execution - has eventually been surrendered to Poland, ${ }^{23}$ the execution of the EAW against $L$ has been refused by the district court of Amsterdam, leading to his immediate release. ${ }^{24}$

It must nevertheless be observed that the Court's use of the 'prevention-of-impunity argument' in $L / P$ is not immediately convincing since it is based on an approach that considers the EAW mechanism in isolation. Such an approach is unduly narrow and fails to take any account of the existence of other judicial cooperation mechanisms through which the perceived 'high risk of impunity' could possibly be reduced.

\section{Existing Alternatives for the EAW to Reduce Impunity Through Judicial Cooperation}

Obvious alternative ways to institute criminal proceedings elsewhere than in the country in which crimes were allegedly committed, and to execute sanctions outside the country where they were imposed, can be established through the transfer of criminal proceedings respectively the transfer of sentences.

943-963. Very critical about this development is A. Klip in his contribution 'Eroding Mutual Trust in an European Criminal Justice Area without Added Value', European Journal of Crime, Criminal Law and Criminal Justice 2020, p. 109-119.

23 District court of Amsterdam, 27 January 2021, ECLI:NL:RBAMS:2021:179. Segments of this verdict has been translated in English, see: https://www.rechtspraak.nl/SiteCollectionDocu ments/4501679623-zaak-kop-tbv-vertaling.pdf.

24 District court of Amsterdam, 10 February 2021, ECLI:NL:RBAMS:2021:420. Segments of this verdict has been translated in English, see: https://www.rechtspraak.nl/SiteCollectionDocu ments/4501679623-zaak-ml-tbv-vertaling.pdf. 


\subsection{Transfer of Criminal Proceedings}

For several conceivable reasons one state can decide to ask another state to take over criminal proceedings that were instituted in the first state. It could for example be that the efficiency of criminal proceedings is better served in the second state where co-defendants are also being prosecuted; or that proceedings in the second state would enhance the suspect's rehabilitation prospects; or would mitigate the impact of the proceedings on the alleged victim who is residing in the second state. Hence, a transfer of proceedings could contribute to the 'proper administration of justice. ${ }^{25}$

The most significant multilateral legal framework that governs the transfer of proceedings in Europe is the 1972 Council of Europe Convention. ${ }^{26}$ Although it has been ratified by a limited number of only 13 EU Member States, ${ }^{27}$ its continued importance in an EU-context is evident because an EU-instrument on the matter is still lacking. Pre-Lisbon efforts to develop an EU Framework Decision have failed, ${ }^{28}$ according to authors due to too much resistance against the proposed obligation to establish subsidiary jurisdiction; this would have entailed an obligatory extension of national jurisdiction on the basis of the transferring state's request to take over criminal proceedings, provided that the transferring state had national jurisdiction. ${ }^{29}$ Outside the 1972 Convention, Member States may also be bound by bilateral treaties.

25 It is generally accepted that a transfer of proceedings should serve this goal, although the objective of serving the proper administration of justice has hardly been codified. See in this regard draft Article 1 of the 2009 draft Framework Decision on transfer of proceedings in criminal matters, oJ 2009, C 219/7: "The purpose of this Framework Decision is to increase efficiency in criminal proceedings and to improve the proper administration of justice within the area of freedom, security and justice".

26 European Convention on the Transfer of Proceedings in Criminal Matters of 15 May 1972, Council of Europe Treaty No. 073 .

27 See: https://www.coe.int/en/web/conventions/full-list/-/conventions/treaty/o73/ signatures?p_auth=Bucyn6Wv (last accessed on 27 March 2021).

28 In 2009 not less than 16 Member States took the initiative to submit a legislative proposal for a Council Framework Decision, foreseeing a detailed procedure, see draft Framework Decision on transfer of proceedings in criminal matters, oJ 2009, C 219/7. After it was concluded that a new proposal should be drawn up post-Lisbon (see Council doc. 16883/1/o9 REV 1), nothing has happened. Perhaps fresh initiatives will follow after the completion of a research project, funded by the European Commission, in the course of which 'possible ways for improvement' are being explored, see https://www.eur.nl/esl/nieuws/ first-newsletter-transfer-proceedings-trop-research-project.

29 B. de Jonge, 'Transfer of criminal proceedings: from stumbling block to cornerstone of cooperation in criminal matters in the EU', ERA Forum 2020, p. 454; M. Luchtman, 'Choice of forum in an area of freedom, security and justice', Utrecht Law Review 2011, p. 81. 
Obviously, transfers of proceedings are least complex if both of the states involved have national jurisdiction over the crimes that have allegedly been committed. In such cases, a transfer may also take place without any specific treaty or agreement applicable but be based on mutual legal assistance arrangements that de facto may lead to a transfer of proceedings - such as the spontaneous exchange of evidence ${ }^{30}$ or the laying of information with a view to proceedings in another country. ${ }^{31}$ Where the receiving state does not yet have jurisdiction on the basis of national law it can only acquire jurisdiction under a treaty, such as the 1972 Convention, or another agreement in which subsidiary jurisdiction is allowed on the basis of the sending state's request to transfer proceedings. ${ }^{32}$

Now, to what extent could an increased employment of transfer of proceedings reduce the risk of impunity that may result from surrender refusals? In pursuing this question, the first relevant matter to turn to concerns the likelihood of jurisdiction in the refusing Member State. Then, the fact that only 13 EU Member States have ratified the 1972 Convention tempers the expectations considerably, ${ }^{33}$ because (bilateral treaties left aside) transfer of proceedings from one EU Member State to another will most of the time require national jurisdiction over the alleged crimes in the receiving Member State and it seems logical to assume that in most cases in which EAW's are issued, no national jurisdiction rests on the executing Member State because otherwise it would probably have instituted criminal proceedings domestically. On the other hand, it is a known fact that EAw's are frequently issued in relation to crimes committed on two or multiple territories (e.g. illegal drug trafficking, trafficking in human beings). It is probably not rarely the case that the territory of the executing Member State is among the involved territories and in such cases the executing Member State would automatically have jurisdiction on the basis of the territoriality principle. But the truth of the matter is that we don't know. As long as comprehensive empirical insights are lacking with respect to the existence of national jurisdiction in the executing Member State

30 Article 7 of the Council Act of 29 May 2000 establishing in accordance with Article 34 of the Treaty on European Union the Convention on Mutual Legal Assistance in Criminal Matters between the Member States of the European Union, OJ 2000, C 197/1. 1959, Council of Europe Treaty No. 03 .

32 See for instance Article 2 of the 1972 Convention, supra note 26.

33 In light of the facts of the cases of $L M$ and $L / P$ it is worth noting that Poland is one of the EU Member States that have not ratified this Convention. 
in EAW cases, ${ }^{34}$ the only justified conclusion can be that the risk of impunity resulting from terminated EAW proceedings (instituted for the purpose of prosecution in the issuing Member State) will be lowered if the Member States involved are able and willing to subsequently employ the option to transfer the criminal proceedings from the issuing to the executing Member State. The very existence of this option and the possibilities for strengthening its use therefore deserves more attention in any reasoning in which the prevention of impunity is put forward to help shaping the limits of fundamental rights assessments in the context of EAW proceedings.

\subsection{Transfer of Sentences}

It follows from Articles 1(1) and 2(1) of the FD EAW that EAW's can be issued for the purpose of executing a custodial sanction that has been imposed by a court in the issuing Member State, provided that the duration of that sanction is at least four months. Would surrender for that purpose be sought but refused, the convicted person will obviously have to be released from provisional detention by the authorities of the executing Member State. ${ }^{35}$ Still, execution of the imposed sanction is not necessarily out of the picture. The Member States involved could alternatively consider to transfer the execution of the penalty to the executing Member State as the convicted person resides there. The applicable rules and conditions governing the transfer of custodial sanctions from one EU Member State to another are envisaged in Framework Decision

34 The only data I know of come from a small study based on published case-law in the period 31 July 2019-31 July 2020 from the District Court of Amsterdam with respect to EAW's issued by Poland. The findings reveal that - based on the information in the judgment - in $53 \%$ of the 19 cases in which an EAw was issued by the Polish authorities for the purpose of prosecution, the Netherlands could exercise national jurisdiction over the offences underlying the Polish EAW's. This study has been carried out in the course of an LL.M. thesis written by S. te Braake under my supervision. A summary (in Dutch) of the findings has been published on Leiden Law Blog: S. te Braake, 'Weigering van overlevering: en wat dan nu?', Leiden Law Blog 9 March 2021, https://leidenlawblog.nl/articles/weigering-van-overlevering-en-wat-dan-nu.

35 Unless the EAW would be refused on the ground that the convicted person is staying in, or is a national or a resident of the executing Member State and that Member State undertakes to execute the custodial sanction, in correspondence with Article 4(6) of the FD EAW. In such a case, the executing Member State is held to execute the custodial sanction without any additional request from the issuing Member State being required, as follows clearly from ECJ 24 June 2019, C-573/17, in the proceedings relating to the execution of the European arrest warrant issued against Daniel Adam Popławski, ECLI:EU:C:2019:530, par. 103. 
2008/909 (FD 2008/909). ${ }^{36}$ They have been implemented in the national laws of all Member States. ${ }^{37}$

To what extent could the transfer of custodial sanctions help to reduce the risk of impunity that may result from refusals to surrender convicted persons? As follows clearly from FD 2008/909, enforcement of a sanction in a Member State other than in which the sanction was imposed must enhance the sentenced person's social rehabilitation. ${ }^{38}$ One may reasonably assume that in cases in which an EAW has been issued for the purpose of sentence enforcement, the convicted person's chances for social rehabilitation can best be achieved in the issuing Member State itself, for otherwise the issuing Member State would already have considered the option of transferring the sentence to the Member State where this person's possibility for social rehabilitation would be better. In view of that, it seems less likely that the transfer of sentences can often be relied on with a view to an increased prevention of impunity across the EU. 39

Logical as that may be, the truth is that FD 2008/909 has not ruled out the possibility that the execution of custodial sanctions is being transferred to a Member State other than in which the purpose of social rehabilitation can best be facilitated, provided that the convicted person is residing in either the issuing Member State or the executing Member State (Articles 3 and 4) - and in EAW cases the latter will obviously the case - and provided that the convicted person's social rehabilitation can somehow be facilitated. After all, under Article 4(1)(c) of FD 2008/909, the judgment may be forwarded to a Member State other than the convicted person's state of nationality in which he lives, and other than the Member State to which the convicted person would be deported after release (Article 4(1)(a) and (b) FD 2008/909) as long as this

36 Framework Decision 2008/909/JHA of 27 November 2008 on the application of the principle of mutual recognition to judgments imposing custodial sentences or measures involving deprivation of liberty for the purpose of their enforcement in the European Union, oJ 2008, $\mathrm{L}_{327} / 27$.

37 https://www.ejn-crimjust.europa.eu/ejn/EJN_Library_StatusOfImpByCat/EN/36 (last accessed on 31 March 2021).

38 See recitals 8 and 9 of the preamble to FD 2008/909 as well as Article 3 of FD 2008/909, supra note 36 .

39 The aforementioned LL.M. study of Te Braake confirms that, see n. 34. The findings of this small study based on published case-law in the period 31 July 2019-31 July 2020 from the District Court of Amsterdam with respect to EAw's issued by Poland reveal that in only 8\% of the cases a transfer of execution of a Polish custodial sanctions to the Netherlands could have been justified on the existence of demonstrable and sufficient links (such as family, social or professional ties) with the Netherlands. 
Member State gives its consent to receiving the enforcement request, ${ }^{40}$ but mostly ${ }^{41}$ without the consent of the sentenced person being required (Article 6(2) FD 2008/909). In such cases, the authorities of the issuing Member State are obliged to consult the authorities of the executing Member State prior to the actual submission of the request, i.e. in order to verify its consent and to verify that sentence enforcement in the executing Member State would serve the convicted person's social rehabilitation (Article 4(2) and (3) FD 2008/909).

All this leaves open the option that in the specific circumstances of the case at hand ${ }^{42}$ the social rehabilitation of the convicted person is pretty well served in the Member State that has refused to surrender him to the Member State in which the custodial sanction has been imposed, but where this person would run a real risk of having his fundamental rights violated after surrender.

It would therefore be justified to pay attention to the capability of the FD 2008/909 mechanism to prevent impunity when shaping the limits of fundamental rights assessments in the context of EAW proceedings.

\section{Conceptualising Impunity Through an Integrative Approach to Judicial Cooperation}

The previous section describes two cooperation mechanisms that may contribute to preventing a high level of impunity in cases in which surrender would be at odds with a generous level of rights protection, but where the protection of rights would not necessarily also be compromised by applying

40 Unless the convicted person lives in and has been legally residing in the executing Member States for at least five years and will retain a permanent right of residence in that Member State - and both the issuing and executing Member States have submitted a notification (under Article 4(7) of FD 2008/909) that the executing Member State's consent is not required in such cases. As follows from Council doc. 9618/1/14 REV 1 of 17 September 2014 (I did not find a more recent overview), only Austria and France have submitted such a notification, meaning that the waiver of consent solely applies in their mutual relationship. After all, under Article 6(2)(c) of FD 2008/909, the consent of the sentenced person is not required when he has fled to the envisaged Member State of execution, or when he has otherwise returned to it in view of the law enforcement activities against him in the Member State in which ultimately a sentence has been imposed. Only outside such situations it is required that the sentenced person consents to a transfer of his sentence to the envisaged Member State.

42 I a recent opinion, Advocate-General Bobek has recognised the importance of an individual examination under Articles 4(1)a and 4(2) FD 2008/909 of the sentenced person's chances to social reintegration in the executing Member State, see the opinion delivered on 3 June 2021 in C-919/19 (XY), ECLI:EU:C:2021:454, par. 76 and 94. The Court's judgment in this case is to be awaited. 
one of these other cooperation mechanisms. How promising the capabilities of these mechanisms can be or will turn out to be in practice, remains to be seen and certainly requires a more in-depth analysis of existing rules and practices. However, it has hopefully been clarified that the mere existence of these other options deserves explicit attention in the ongoing discussion on the limits of mutual recognition in EAW cases, and hence in the use of the prevention-of-impunity argument. Consequently, in an attempt to help shape a true and comprehensive European concept of impunity, this contribution favours an integrative approach towards cross-border cooperation in the EU criminal justice area - i.e. an approach in which mutual recognition instruments and judicial cooperation mechanisms provide a coherent series of possibilities from which the most appropriate one should be used in each individual case.

To that end, the following builds on the work of Mitsilegas who in a recent contribution identified the need to develop a 'European concept of impunity', such as in the construction of the Area of Freedom, Security and Justice in which impunity has particularly been fought through a system of cross-border cooperation based on the principle of mutual recognition. ${ }^{43}$ Following his analysis that the quest for fighting impunity within this context has shown a clear priority for the objectives of effective and speedy enforcement in the criminal justice system of the issuing Member State, Mitsilegas advocates the development of what he calls a 'rights-based concept of impunity', i.e. a concept of impunity that is 'underpinned by full respect of EU values, and in particular the protection of fundamental rights and the rule of law'. According to him, steps have already been taken towards such a concept - as is not only apparent from the Court's case-law in which mutual trust was held to be rebuttable on fundamental rights grounds, but also follows from other developments such as the extensive legislative harmonisation of defence rights. Then, in order to further shape the envisaged 'rights-based concept of impunity', Mitsilegas observes the need to rethink the elements of time, space and the actors of anti-impunity. 44

It must be admitted that I am not sure if I fully understand the notion of a 'rights-based concept of impunity' as put forward by Mitsilegas. In the picture he describes of it, the - in itself legitimate - interests of law enforcement

\footnotetext{
43 Mitsilegas 2020, supra footnote 17. In this rich piece of work, the author provides an analysis of the fight against impunity in EU law from two other perspectives outside the need to build an Area of Freedom, Security and Justice, i.e. the need to protect the EU financial interests and the external dimension of anti-impunity, such as in the context of extradition relationships between EU Member States and third states. 
and punishment have not been mentioned explicitly, and hence seem to have faded into the background, which raises the question of how balanced the envisaged notion of impunity actually is. Still, it provides a welcome and helpful proposition to build on. In the framework of this contribution it is the particular element of space that deserves brief attention. Rethinking the element of space comprises a reflection on what the EU criminal justice area actually entails, both in physical and in legal terms, and furthermore, what it should entail in order to shape the aforementioned 'rights-based concept of impunity'. Mitsilegas apparently assumes that a European concept of impunity requires a 'borderless AFSJ' instead of an AFSJ consisting of national legal territories and jurisdictions. His remark that ' $[t]$ ensions between developing a European concept of anti-impunity within a borderless AFSJ on the one hand and national priorities and considerations on the other have been present almost throughout this analysis' suggests that he considers both perspectives as often opposite to each other. ${ }^{45}$ If that is the case indeed, I would like to put forward the integrative approach towards cross-border criminal justice cooperation as a promising response, for I believe it has the capability to naturally reconcile the priorities of a borderless AFSJ with the priorities of national legal orders. Under an integrative approach national authorities would be demanded to consider alternative options to cooperate in cases in which the way originally foreseen would be at odds with a sufficient safeguarding of fundamental rights and the rule of law. Thereby, cooperation is more likely to satisfy the legitimate wish to combat crime and prevent impunity, also across national borders, while at the same time fair account is taken of the rights of the individual involved. Precisely because of that, an approach in which cross-border criminal justice cooperation is viewed as an integrated whole must be promoted anyway, also beyond situations of contradicting priorities between European versus national levels of enforcement. The use of an integrative approach fosters the adequate safeguarding of all interests that are at stake in a cross-border criminal justice area, and this approach should therefore be incorporated in the further conceptualisation of impunity in the EU criminal justice area. Hence, it should be incorporated in courts' reasonings in which the prevention of impunity will be brought up in relation to the issue of fundamental rights assessments in EAW proceedings or other judicial cooperation proceedings.

45 Idem, p. 44. 


\title{
$5 \quad$ Closing Remarks
}

The EAW mechanism is not the sole mechanism to do justice across borders. If surrender to another Member States either will, or is likely to compromise the fundamental rights of the sought person, the options for the executing authorities are not necessarily limited to 'surrender anyway' and 'no surrender, hence impunity'. Alternative options may come into view as well, such as the transfer of proceedings or the transfer of the execution of sentences. Such alternatives obviously require a willing attitude of both Member States involved, but could satisfy both the wish to avoid impunity and the requirement to adequately protect fundamental rights in cases in which surrender would not have been able to meet both interests. In the joined $L / P$ cases, the EU Court of Justice has failed to merely mention the existence and capabilities of other cooperation mechanisms. This is why the Court's reliance on the prevention-of-impunity argument in these cases is unconvincing.

This contribution has attempted to demonstrate to need for an integrative approach to judicial cooperation mechanisms in the EU criminal justice area, and the promises of such an approach in conceptualising a European concept of impunity. Proper attention for other cooperation mechanisms and their capabilities in reducing the number of criminal offences going unpunished would reopen the question of whether, and to what extent in cases such as those at hand in $L / P$, the second step - i.e. the individual assessment - could be dropped or whether it could perhaps be shaped differently, namely in such a way that the authorities of both countries involved would be stronger encouraged, or even required to consider alternatives for surrender. That way, the envisaged integrative approach would facilitate the proper administration of justice across the EU territory, even in times of serious rule of law concerns in some of the EU Member States.

\author{
Jannemieke Ouwerkerk \\ Editor-in-Chief, Institute of Criminal Law and Criminology, Leiden \\ University, Leiden, the Netherlands \\ j.w.ouwerkerk@law.leidenuniv.nl
}

